\title{
The Effects of Learning Management Systems (LMS) on Mathematics Achievement: A Meta-Analysis Study
}

\author{
Hatice SAYGILI ${ }^{1}$, Hatice ÇETİN ${ }^{2}$ \\ ${ }^{1}$ Necmettin Erbakan University, saygilitch20@gmail.com \\ http://orcid.org/0000-0003-1250-6538 \\ 2 Necmettin Erbakan University, haticebts@gmail.com, \\ http://orcid.org/0000-0003-0686-8049
}

Received : 21.11 .2021

Accepted : 21.12.2021

Doi: 10.17522/balikesirnef.1026534

\begin{abstract}
The purpose of this investigation is to examine the effect of LMS (Learning Management System) use on students' mathematic achievement through a meta-analysis method. 43 experimental studies with a data set including standard deviations, mean scores and sample sizes were incorporated in the analysis. The total number of samples from the studies included in the analysis is 15.296. Data were analyzed using Comprehensive Meta Analysis (CMA) software. After the analysis was completed in accordance with the random effects model, the Cohen d effect value of LMS use on students' mathematics achievement was calculated as 0.363 . The results of the subgroup analysis of this effect size value indicated that the effect of LMS use on mathematics achievement did not differ significantly between subgroups with reference to the variables of sample, type of publication, duration of application and method of application. On the other hand, it was found that there was a significant difference between the subgroups for the variables of year, country, subject and education level.
\end{abstract}

Key words: Learning management system, mathematics achievement, meta- analysis.

Corresponding author: Hatice ÇETİN, haticebts@gmail.com

\section{Introduction}

The pandemic, which has taken the whole world under its influence for the last few years, has also affected education systems. The extraordinary situation that we are in has led us to turn to distance education from face-to-face education. With the benefits of innovative educational technologies, the boundaries of educational activities have expanded. (Chang, et 
al., 2015). One of the tools in which distance education activities are actively presented is learning management systems (LMS).

LMS is software that supports access to a wide variety of web-enabled tools for conducting, compiling, managing and documenting educational activities (Cole \& Foster, 2008; Ellis, 2009). In other words, LMS is software that combines online learning tools in learning and teaching using internet technologies (Avgeriou, et al., 2003). LMS has allowed students to communicate and evaluate each other during the education process. LMS has also enabled students to access necessary materials for the course and to choose appropriate activities (Adzharuddin \& Ling, 2013). LMS has many features such as accessing lessons without the restrictions of time and place, supporting different languages and providing fun activities suitable for students' interests (Beam \& Cameron, 1998). In this respect, the process in which the teacher is at the forefront in traditional education has left its place to the active participation of students with the use of LMS.

LMSs used today can be classified as open source products, commercial products and customized software (Avgeriou, et al., 2003). The most common of open source learning management systems include Moodle (used in 220 countries around the world), Claroline, Interact, Ilias, Sakai, Canvas, which were utilized in many countries.

It has been suggested online learning environments have increased the effectiveness of virtual learning with online communications such as e-mail and live question and answer sessions (Massoud, Iqbal \& Stockley, 2011; Lee, 2019; Nwaogu, 2012). To put it another way, the online learning environment is considered important in that it includes the learningteaching process without the limitation of time and place, and presents opportunities that cannot be provided in the traditional classroom environment (Woolley \& Ludwig, 2000).

There have been meta-analysis studies in which different technology-supported methods are concerned with mathematics achievement (Chadwick, 1997; Chan \& Leung, 2014; Deniz, 2019; Lee 1990; Li \& Ma, 2010; Tokpah 2008; Young \& Hamilton, 2018; Schenker, 2007; Steenbergen-Hu \& Cooper, 2013). Studies examining the effect of LMS, which are widely used in the distance education process today, on mathematics achievement also form the backbone of this research. In the relevant literature, it is seen that LMS provides convenience in learning and teaching processes (Guzer \& Caner, 2014) and that it is preferred in integrating methods of flipped learning, blended learning, web based learning, online learning (Boyd, 2018; Crowley, 2018; Francis, 2016; Huang, 2012; Korucu \& Kabak, 2020; Kwan lo \& Foon, 2017; Liu, 2010; Newberry, 2011; Odom, 2006; Özerbaş, 2012; Renee, 2017; 
Şahinoğlu, 2012; Tarazi, 2016 ; Toth, 2013; Winn, 2016; Zenati, 2020) which have been distinctive and popular in recent years.

Some research results indicate that the use of LMS positively affects mathematics achievement at different levels (Bradley, 2016; Chaney, 2016; Crowley, 2018; Comfort, 2016; Day, 2017; Kelismail, 2019; Nies, 2018; Olpak, et al., 2018; Osborne, 2020; Şimşek, 2010; Tekin, 2018; Telford, 2011; Williamson, 2017; You, 2015). On the other hand, there are also study results that show that the use of LMS has no effect on mathematics achievement (Anthony, 2015; Applebee, 2019; Belanger, 2018; Cheung \& Slavin, 2013; Francis, 2016; Gangaram, 2014; Ichinose, 2011; Mills, 2016; Norvell, 2017; Pope, 2013; Renee, 2017; Smith, 2017; Williamson, 2017). This inconsistency in the results of the research necessitated revealing the real effect of the use of LMS in mathematics education on students' mathematics achievement. In fact, can we really say that LMS is so effective and efficient in terms of mathematical success in today's world where educational technologies have developed so much as mentioned above? Within the scope of this study, answers to the following questions were sought by systematically compiling LMS studies in the field of mathematics education:

1. What is the overall effect of LMS use on mathematics achievement?

2. Does the overall effect of LMS use on mathematics achievement differ significantly within the study subgroups (publication year, country, sample group, application period, education level, subject, publication type and application method)?

The present study can be seen essential as it presents a general conclusion about how effective the use of LMS is on mathematics achievement. It can also be considered up-to-date in terms of addressing LMS technology, which is one of the most popular and widely used educational technologies today. Finally, the present study can be regarded as original due to the lack of studies examining the effect size of LMS use in education on mathematics achievement. On the other hand, this study is limited to articles and theses made in the last fifteen years that can be accessed in specific databases examining the effect of LMS use on mathematics achievement. 


\section{Method}

In this study, the meta-analysis method was employed to investigate the effect of LMS use on mathematics achievement. Meta-analysis is a method used to compile the results of the studies and statistically interpret the actual effect sizes (Borenstein, et al., 2009; Cohen, Manion \& Morrison, 2007). The findings from experimental studies investigating the effect of LMS on mathematics achievement were combined with meta-analysis method and random effects model was used. The random effects model is applied when the population sizes of the included studies are different, the standard deviation is not equal to zero, and the study is heterogeneous (Borenstein, et al., 2009).

\section{Inclusion and Exclusion Criteria}

The studies included in the present analysis were chosen based on the following criteria:

- Master's thesis, doctoral thesis and articles examining the effects of LMS on students' mathematics achievement,

- the studies with an experimental design,

- the studies with sample sizes, mean scores and standard deviation values to calculate the effect in meta-analysis,

- the studies comparing the traditional method with LMS using,

- the national and international studies published from 2005 to December 2020,

- $\quad$ the studies indexed in National Thesis Center, Proquest and Web of Science (WoS) databases

- by taking the LMS definitions specified in the conceptual framework as criteria the studies were included in the analysis.

During the meta-analysis process, the flow in the updated Preferred Reporting Items for Systematic Reviews and Meta Analyses (PRISMA 2020) guideline (http://prismastatement.org/prismastatement/Checklist.aspx) was followed. In this respect, the sample of the study consists of master's theses, doctoral thesis and articles examining the effects of LMS on students' mathematics achievement. To this end, National Thesis Center, Proquest and WoS databases were scanned. During the process of scanning, the key words of "Learning Management System”AND “math*” AND "success OR accomplish* OR acquire*” 
were used. The studies obtained as a result of the scanning were examined in terms of suitability for the purpose. As a consequence, 4,503 articles and theses were listed, of which 3.231 experimental studies were identified. The contents of the experimental studies were examined in detail and 83 studies with pre-test-post-test experimental and control group designs were chosen. As a result of the exclusion of studies lacking mean scores and standard deviation values, a total of 43 studies were included in the final analysis. Of the 43 studies, 6 were articles, 4 were national theses and 33 were international thesis.

\section{Coding Procedure and Reliability}

Within the scope of the analysis, the overall effect of LMS use on mathematics achievement was also examined within some subgroups. These were coded as publication year, country, sample group, application period, education level, subject, publication type and application method. Kappa reliability value (.88) among the coders showed a satisfactory level of agreement (Cohen, 1960).

\section{Data Analysis}

Comprehensive Meta-Analysis (CMA) version.3 software was used to analyze the data. After performing the heterogeneity test, the effect size was calculated for the random effects model. When deciding on the random effects model, it was taken into account that the included studies did not have a common effect size and showed a heterogeneous structure (Borenstein, et al., 2009). To calculate the effect size, Cohen's d factor was used. When the effect size was calculated, the effect level classification was done as follows: $-0,15 \leq$ Cohen $d$ $<0,15$ insignificant, $0,15 \leq$ Cohen $\mathrm{d}<0,40$ small effect, $0,40 \leq$ Cohen $\mathrm{d}<0,75$ moderate effect, $0,75 \leq$ Cohen $\mathrm{d}<1,10$ large effect, $1,10 \leq$ Cohen $\mathrm{d}<1,45$ extremely large effect, $1,45 \leq$ Cohen d strong effect (Thalheimer \& Cook, 2002). After the effect size was calculated, moderator analysis was performed to determine whether the effect size differed within the subgroup variables. Analog Anova was preferred as moderator variables were categorical (Aguinis, Gottfredson, \&Wright, 2011). Whether there is publication bias in the studies included in the meta-analysis was examined by funnel plot, Orwin's Fail Safe N and Egger's regression analysis.

\section{Findings and Discussion}

\section{Publication Bias}


In this section, Funnel plot, Orwin's Fail Safe N and Egger's Regression analysis findings will be reported to evaluate publication bias. The funnel plot shows the distribution of the effect sizes for the specified sample sizes of the studies included in the meta-analysis. The absence of publication bias can be identified by the symmetrical view of the funnel plot (Card, 2012).

The funnel scatter plot of the studies included in the meta-analysis is presented in Figure 1 below

Funnel Plot of Standard Error by Std diff in means

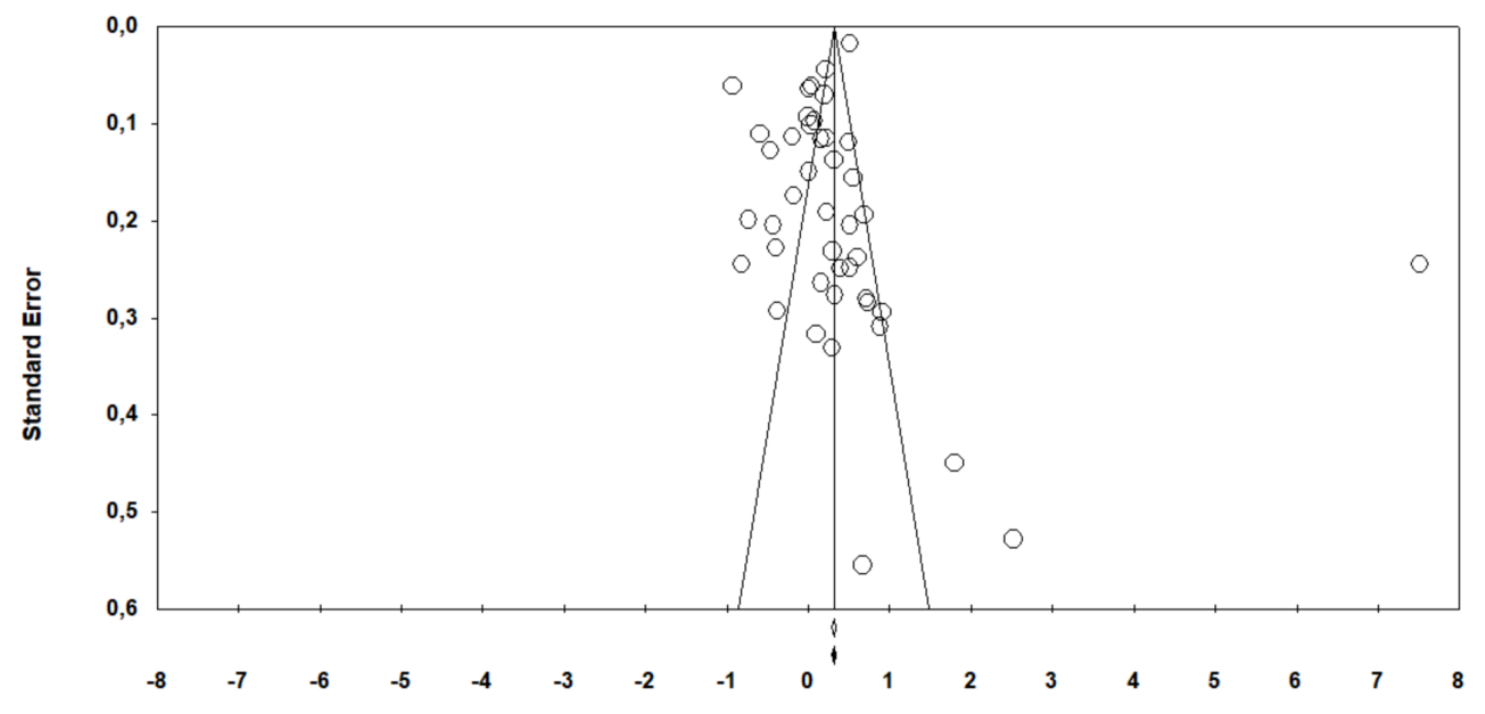

Figure 1. Funnel Plot

As seen in Figure 1, most of the studies were placed in the funnel scattered and they were centered around the average effect size. In the funnel plot, the studies are expected to show a symmetrical distribution. However, when the funnel plot is examined, it is seen that the studies do not show a symmetrical distribution. To ensure symmetry, Duval and Tweedie's (2000) trim and fill method was employed. The new funnel plot is as in Figure 2 below. 
Funnel Plot of Standard Error by Std diff in means

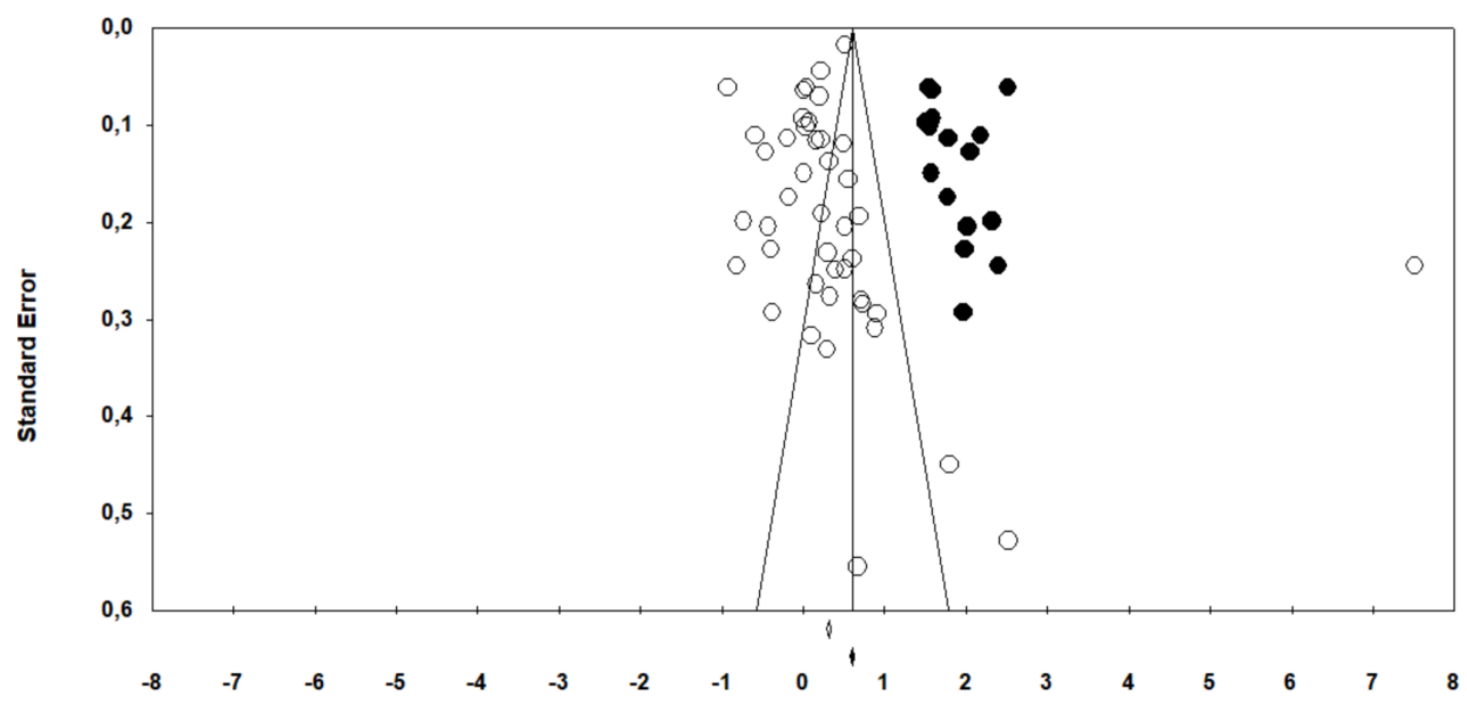

Figure 2. The Funnel Plot resulted from Trim and Fill

As seen in Figure 2, the effect size could increase on condition that 16 more studies were to be added to the present investigation (Cohen's $d=0.600)$. Another publication bias test is Orwin's Fail Safe N test. Orwin's Fail Safe N is a statistic that numerically shows how many more studies were to be included in this meta-analysis study to show that the calculated effect size would decrease to a meaningless value (Orwin, 1983). The numerical data from Orwin's Fail Safe N test are presented in Table 1 below.

Table 1. Orwin's Fail Safe N Test Results

\begin{tabular}{lc}
\hline Element & Value \\
\hline Z-score & 12.858 \\
$\mathrm{p}$ & 0.00 \\
Alfa & 0.05 \\
Z score for Alfa & 1.959 \\
$\mathrm{~N}$ & 43 \\
The number of missing & 1808 \\
studies & \\
\hline
\end{tabular}

When Table 1 is examined, the Orwin's Fail Safe N results of 43 studies included in the meta-analysis are seen. According to these results, the number of studies that can reduce the effect size to invalid degree is 1808 . The 43 studies included in the meta-analysis had the number to meet both national and international criteria. Since it was not possible to reach 
1808 studies more, it can be stated that there is no publication bias according to this test result. Table 2 below presents Egger's regression values.

Table 2. Egger's Regression Test Results

\begin{tabular}{lc}
\hline Element & Value \\
\hline t Value & 0.707 \\
df & 41.000 \\
P Value (1-tailed) & 0.241 \\
P Value (2-tailed) & 0.483 \\
\hline
\end{tabular}

When Table 2 is examined, Egger's regression results of 43 studies included in the meta-analysis are seen. The finding that Egger test result is not statistically significant, ( $p>.05)$ indicates that there is no publication bias.

\section{Heterogeneity and Effect Size}

The results of the heterogeneity test results are presented in Table 3 below:

Table 3. Heterogeneity test and effect size results

\begin{tabular}{|c|c|c|c|c|c|c|c|c|c|c|}
\hline Model & $\mathbf{N}$ & ES & $\mathbf{Z}$ & SD & $\% 9$ & $\begin{array}{l}\text { confidince } \\
\text { interval }\end{array}$ & df & $\mathbf{Q}$ & $\mathbf{P}$ & $\mathbf{I}^{2}$ \\
\hline & & & & & Belo & Above & & & & \\
\hline Random & 43 & 0.363 & 3.546 & 0.10 & 0.162 & 0.564 & 42 & 1763.58 & 0.000 & 97.094 \\
\hline Fixed & 43 & 0.311 & 24.824 & 0.01 & 0.286 & 0.335 & 42 & & & \\
\hline
\end{tabular}

It is seen in Tablo 3 that the $Q$ value is 1763.580 . Since this value is greater than the chi-square value at 42 degrees of freedom and $\mathrm{I}^{2}=97.094$, it is concluded that the studies show heterogeneous distribution $(\mathrm{p}=0.000)$. In order to determine whether the effect sizes of the studies included in the meta-analysis show a homogeneous distribution or not, $\mathrm{p}, \mathrm{Q}$ veya $\mathrm{I}^{2}$ values are taken into consideration. When the $\mathrm{p}$ value is smaller than 0.05 and the $\mathrm{Q}$ value is greater than df value, it is concluded that the studies are heterogeneous (Dinçer, 2014). The level of heterogeneity is also measured according to the $\mathrm{I}^{2}$ statistical result. The $\mathrm{I} 2$ result is consider low if $25 \%$, medium if $50 \%$ and high if $75 \%$ (Higgins, et al., 2003).

Now that the studies included in the analysis showed a heterogeneous distribution, the effect size (Cohen d) value was calculated with reference to the random effects model and evaluations were done accordingly. Based on the random effects model, the effect size value 
is 0.363 . Both effect size values are small and positive and statistically significant $(\mathrm{p}<.05)$.

Considering the effect size value, it can be said that LMS-based instruction has a small effect on mathematics achievement.

The forest plot of 43 studies analyzed with the random effects model is given in Figure 3.

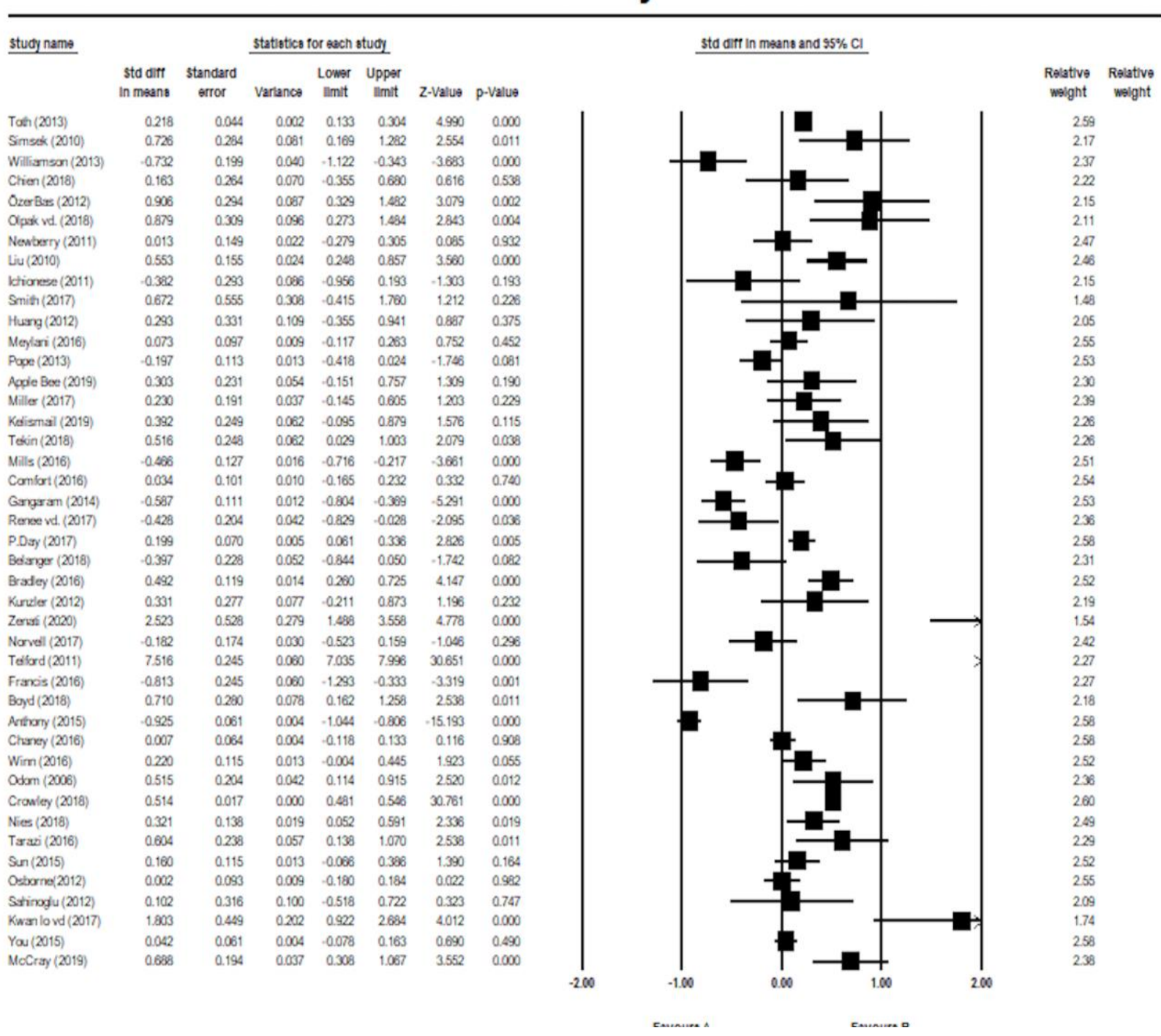

Figure 3. Forest Plot analyzed with the random effects model

A closer look at Figure 3 indicates that the largest effect size is 7,516 (Telford, 2011) and the smallest is -0.925 (Anthony, 2015). Considering the lower limit and upper limit values of the effect sizes, one can note that it varies between 1,293 (Francis, 2016) and 7,996 (Telford, 2011). It is seen that the $\mathrm{p}$ value is statistically significant $(\mathrm{p}<.05)$ in 23 studies included in the study, while 20 studies did not indicate statistical significance (p>.05). Based 
on Thalheimer and Cook (2002), the classification of the effect sizes of the studies included in the forest chart is shown in Table 4.

Table 4. Effect Size Classification of Studies Included in Meta-Analysis

\begin{tabular}{lc}
\hline Effect Size Classification & Number of Studies \\
\hline Insignificant & 17 \\
Small & 10 \\
Moderate & 11 \\
Strong & 5 \\
\hline Total & 43 \\
\hline
\end{tabular}

Table 4 shows that there are 17 studies at an insignificant level, 10 at a small level, 11 at a moderate level and 5 at a strong level. Concerning the first problem statement of the study, the findings of 43 studies included in the meta-analysis with different effect sizes were combined and included in the analysis.

The difference between the effect sizes of studies investigating the effect of LMS use on mathematics achievement may depend on the independent variables of the studies included in the analysis. For this reason, the second subproblem "Does the overall effect of LMS use on mathematics achievement differ significantly by study subgroups (year of publication, country, sample group, duration of application, level of education, subject, type of publication, and method of application)?" was identified in this way. Depending on these variables, Analog Anova results are presented in Table 5.

Table 5. Sub-group analysis according to random effects model

\begin{tabular}{|c|c|c|c|c|c|c|c|c|c|}
\hline & & & & & $\begin{array}{r}\% 95 \\
\text { In }\end{array}$ & $\begin{array}{l}\text { Ifidence } \\
\text { val }\end{array}$ & & & \\
\hline \multirow[t]{4}{*}{ Moderator } & Variable & $\mathbf{N}$ & ES & SE & Below & Above & df & QB & $\mathbf{p}$ \\
\hline & 2006 & 1 & 0.515 & 0.204 & 0.114 & 0.915 & & & \\
\hline & 2010 & 2 & 0.592 & 0.136 & 0.325 & 0.859 & & & \\
\hline & 2011 & 3 & 2.382 & 2.485 & -2.488 & 7.252 & & & \\
\hline \multirow{8}{*}{ 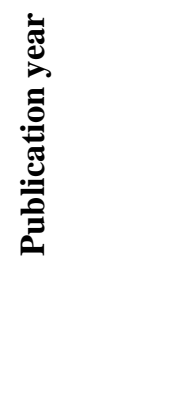 } & 2012 & 5 & 0.280 & 0.168 & -0.051 & 0.610 & & & \\
\hline & 2013 & 3 & -0.204 & 0.245 & -0.684 & 0.275 & & & \\
\hline & 2014 & 1 & -0.587 & 0.111 & -0.804 & -0.369 & & & \\
\hline & 2015 & 3 & -0.244 & 0.369 & -0.967 & 0.480 & 11 & 94.404 & 0.000 \\
\hline & 2016 & 8 & 0.033 & 0.111 & -0.185 & 0.251 & & & \\
\hline & 2017 & 6 & 0.211 & 0.189 & -0.159 & 0.581 & & & \\
\hline & 2018 & 7 & 0.374 & 0.123 & 0.132 & 0.615 & & & \\
\hline & 2019 & 3 & 0.493 & 0.127 & 0.243 & 0.743 & & & \\
\hline
\end{tabular}




\begin{tabular}{|c|c|c|c|c|c|c|c|c|c|}
\hline & 2020 & 1 & 2.523 & 0.528 & 1.488 & 3.558 & & & \\
\hline & Total & 43 & 0.162 & 0.047 & 0.070 & 0.253 & & & \\
\hline \multirow{7}{*}{ 总 } & Turkey & 6 & 0.579 & 0.118 & 0.347 & 0.810 & \multirow{7}{*}{5} & \multirow{7}{*}{20.122} & \multirow{7}{*}{0.001} \\
\hline & USA & 31 & 0.359 & 0.139 & 0.087 & 0.631 & & & \\
\hline & China & 3 & 0.440 & 0.536 & -0.611 & 1.491 & & & \\
\hline & South Africa & 1 & 0.013 & 0.149 & -0.279 & 0.305 & & & \\
\hline & Korea & 1 & 0.042 & 0.061 & -0.078 & 0.163 & & & \\
\hline & Hungary & 1 & 0.218 & 0.044 & 0.133 & 0.304 & & & \\
\hline & Total & 43 & 0.196 & 0.032 & 0.132 & 0.259 & & & \\
\hline \multirow{5}{*}{ 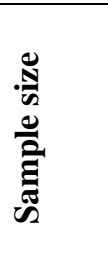 } & $0-100$ & 25 & 0.413 & 0.179 & 0.062 & 0.764 & \multirow{5}{*}{3} & \multirow{5}{*}{3.060} & \multirow{5}{*}{0.382} \\
\hline & $101-200$ & 8 & 0.108 & 0.174 & -0.234 & 0.449 & & & \\
\hline & $201-300$ & 6 & 0.531 & 0.189 & 0.162 & 0.901 & & & \\
\hline & Above 301 & 4 & 0.246 & 0.298 & -0.338 & 0.830 & & & \\
\hline & Total & 43 & 0.330 & 0.098 & 0.137 & 0.523 & & & \\
\hline \multirow{5}{*}{ 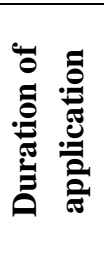 } & $0-5$ & 13 & 0.277 & 0.079 & 0.122 & 0.433 & \multirow{5}{*}{3} & \multirow{5}{*}{3.257} & \multirow{5}{*}{0.354} \\
\hline & $6-10$ & 21 & 0.481 & 0.206 & 0.076 & 0.885 & & & \\
\hline & $11-15$ & 7 & 0.143 & 0.085 & -0.024 & 0.310 & & & \\
\hline & Above 16 & 2 & 0.017 & 0.348 & -0.665 & 0.700 & & & \\
\hline & Total & 43 & 0.229 & 0.055 & 0.121 & 0.337 & & & \\
\hline \multirow{5}{*}{ 苂 总 } & Primary & 2 & 0.515 & 0.017 & 0.482 & 0.547 & \multirow{5}{*}{3} & \multirow{5}{*}{16.268} & \multirow{5}{*}{0.001} \\
\hline & Secondary & 11 & 0.146 & 0.108 & -0.066 & 0.358 & & & \\
\hline & High School & 11 & 0.070 & 0.206 & -0.333 & 0.474 & & & \\
\hline & University & 19 & 0.651 & 0.207 & 0.244 & 1.057 & & & \\
\hline & Total & 43 & 0.505 & 0.016 & 0.473 & 0.537 & & & \\
\hline \multirow{13}{*}{$\begin{array}{l}\bar{e} \\
\frac{\mathscr{E}}{\bar{E}} \\
\bar{E}\end{array}$} & Algebra & 18 & 0.546 & 0.217 & 0.122 & 0.971 & \multirow{13}{*}{11} & \multirow{13}{*}{36.253} & \multirow{13}{*}{0.000} \\
\hline & Operations & 9 & 0.024 & 0.192 & -0.352 & 0.400 & & & \\
\hline & Fraction & 4 & 0.362 & 0.177 & 0.016 & 0.708 & & & \\
\hline & Probability & 3 & -0.099 & 0.359 & -0.803 & 0.605 & & & \\
\hline & Integral & 2 & 0.383 & 0.245 & -0.099 & 0.864 & & & \\
\hline & Derivative & 1 & 0.726 & 0.284 & 0.169 & 1.282 & & & \\
\hline & $\begin{array}{l}\text { Arithmetic and } \\
\text { geometry }\end{array}$ & 1 & 1.803 & 0.449 & 0.922 & 2.684 & & & \\
\hline & Cylinder & 1 & 0.906 & 0.294 & 0.329 & 1.482 & & & \\
\hline & Measure & 1 & 0.042 & 0.061 & -0.078 & 0.163 & & & \\
\hline & $\begin{array}{l}\text { Algebraic } \\
\text { expressions }\end{array}$ & 1 & 0.516 & 0.248 & 0.029 & 1.003 & & & \\
\hline & $\begin{array}{l}\text { Quadrilateral } \\
\text { and polygon }\end{array}$ & 1 & 0.102 & 0.316 & -0.518 & 0.722 & & & \\
\hline & Sequences & 1 & 0.392 & 0.249 & -0.095 & 0.879 & & & \\
\hline & Total & 43 & 0.192 & 0.048 & 0.099 & 0.286 & & & \\
\hline \multirow{4}{*}{ 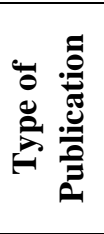 } & Article & 6 & 0.427 & 0.133 & 0.166 & 0.688 & \multirow{4}{*}{2} & & \\
\hline & National Thesis & 4 & 0.451 & 0.135 & 0.187 & 0.716 & & & \\
\hline & $\begin{array}{l}\text { International } \\
\text { Thesis }\end{array}$ & 33 & 0.324 & 0.133 & 0.063 & 0.584 & & 0.518 & 0.772 \\
\hline & Total & 43 & 0.400 & 0.077 & 0.249 & 0.551 & & & \\
\hline & Online & 28 & 0.630 & 0.254 & 0.132 & 1.127 & & & \\
\hline 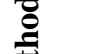 & Blended & 6 & 0.003 & 0.131 & -0.254 & 0.259 & & & \\
\hline Е & Flipped & 4 & -0.060 & 0.153 & -0.359 & 0.240 & 3 & 5.890 & 0.117 \\
\hline & Web-based & 5 & 0.004 & 0.237 & -0.460 & 0.468 & & & \\
\hline
\end{tabular}


According to Table 5, when we examine the heterogeneity test results of the subgroups measured in accordance with the variable of publication year, it is seen that there is a significant difference between the subgroups $(\mathrm{Q}=94.404 ; \mathrm{p}<.05)$. Based on this finding, it could be said that mathematics achievement in the use of LMS is affected by years. The highest effect size value is observed in a study conducted in 2020 and the lowest effect size in the studies conducted in 2014. It can be thought that the studies and dissemination activities on LMS in recent years have increased the effectiveness.

When the results from the variable of country are analyzed, it is noted that there is a significant difference between the subgroups $(\mathrm{Q}=20.122 ; \mathrm{p}<.05)$. With regard to this finding, it can be argued that mathematics achievement varies in accordance with the country subgroup as a result of the LMS use. The highest effect size is seen in the studies conducted in Turkey and the lowest effect size is seen in the study conducted in South Africa.

As far as the findings from the variable of sample size are concerned, it is observed that there is no significant difference between the subgroups $(Q=3.060 ; p>.05)$. This suggests that mathematics achievement as a result of using LMS is not affected by sample size. Similarly, the results from the variable of application time indicates no significant difference between the subgroups $(\mathrm{Q}=3.257 ; \mathrm{p}>.05)$. This points out that the application time has no effect on achieving mathematical success in the use of LMS.

The data from the variable of education level reveals that there is a significant difference $(\mathrm{Q}=16.268 ; \mathrm{p}<.05)$. It is seen that the effect size values of the studies at the university level are higher than the effect sizes at other levels (primary school, secondary school, high school). It can be stated that the lowest effect size is in the studies at the high school level.

The findings obtained for the variable of subject displays that there is a significant difference between the subgroups $(\mathrm{Q}=36.253$; $\mathrm{p}<.05)$. With reference to this result, it can be argued that mathematics achievement obtained with the use of LMS varies according to the subject of mathematics. Based on this data, it can be expressed that the highest effect size value is in the study that deals with arithmetic and geometry, and the lowest effect size value is in the study that deals with the subject of probability. Finally, no significant difference was 
noted between the subgroups for the variable of type of publication $(\mathrm{Q}=0.518 ; \mathrm{p}>.05)$ and the method of application variable $(\mathrm{Q}=5.890 ; \mathrm{p}>.05)$.

This meta-analysis study aimed to investigate the effect of LMS use on mathematics achievement. After running the analysis based on the random effects model, it was revealed that the overall effect of the use of LMS on mathematics achievement was small ( $E S=0.363)$. The results obtained from the research demonstrates that the teaching carried out with the use of LMS does not increase student achievement at satisfactory levels. This finding is in compliance with that of Cheung and Slavin (2013) (ES=0.15). It can be argued that the evidence indicating that the role of LMS use in gaining mathematics achievement is not found to be highly essential might result from the abstract nature of the mathematics discipline and the fact that it requires real classroom practice involving physical-concrete activities.

The studies included in the present investigation are analyzed and compared among themselves and it was revealed that while some studies did not find a significant effect for LMS use on mathematics achievement (Anthony, 2015; Belanger, 2018; Francis, 2016; Gangaram, 2014; Ichinose, 2011; Mills, 2016; Norvell, 2017; Pope, 2013; Renee, 2017; Williamson, 2017), others suggested a significant effect for the use of LMS (Bradley, 2016; Kunzler, 2012; Meylani, 2016; McCray, 2019; Telford, 2011; Toth, 2013; You, 2015). In some meta-analysis studies examining the effects of different methods on mathematics achievement during the mathematics education, it is seen that similar effect sizes were obtained as in the current study. For instance, the findings that computer assisted instruction (Chadwick, 1997; Lee 1990; Li \& Ma, 2010; Tokpah 2008; Young \& Hamilton, 2018); the use of technology in instruction (Cheung \& Slavin, 2013, Schenker, 2007) the smart education systems (Steenbergen-Hu \& Cooper, 2013) had a very low impact on mathematics achievement are in line with the results of the present study. The effect size of these studies is quite small and does not account for the expected effect.

In this study, it was discovered that the effect of LMS use on mathematics achievement did not lead to significant difference among the groups for the variables of sample size, publication type, application method and duration of application. In this research, when the included studies are examined with reference to sample sizes, it is seen that the effect size values of the studies with small samples are higher than those with large samples. A closer look at the available literature shows that there are studies supporting this finding (Cheung \& Slavin, 2013; Çelik, 2013; Young \& Hamilton, 2018). In this study, it is seen that 
flipped learning, blended learning, web-based learning and online learning methods are disputable because of the divergent results they produced. For example, it was demonstrated that while in some studies hybrid learning (Crowley, 2018; Francis, 2016; Korucu \& Kabak, 2020; Renee, 2017; Winn, 2016; Zenati, 2020), flipped learning (Kwan lo \& Foon, 2017; Tekin, 2018; Tarazi, 2016) and web based learning (Toth, 2013; Özerbaş, 2012) generated a positive effect on mathematics achievement, in other studies online learning methods had no effect on achievement (Anthony, 2015; Boyd, 2018; Chaney, 2016; Huang, 2012; Ichinose, 2011; Newberry, 2011; Norvell, 2017; Nies, 2018; Odom, 2006; Osborne, 2020; Pope, 2013; Şahinoğlu, 2012; Telford, 2011).

The results of the analysis yielded that the difference between the groups was significant for the variables of year of publication, country, education level and subject. When the effect size value is examined for the subject variable, it is shown that the highest effect size is in the study that deals with the subject of Arithmetic and Geometry. Chan and Leung (2014) researched computer assisted geometry teaching through the meta-analysis method and attained a high level of effect. Similarly, Deniz (2019) examined technology-assisted geometry teaching by employing a meta-analysis method and found a high effect size. It can be stated that these findings are in parallel with the findings of the current study.

\section{Conclusions and Suggestions}

Based on the results of this investigation, it can be claimed that LMS use has a small effect on mathematics achievement. This value shows that the use of LMS does not account for mathematics achievement at a high level, according to the results of 43 experimental studies involving 15.296 students. In this study, no significant difference was observed between the groups for the variables of sample size, duration of application, application method and publication type. On the other hand, it has been revealed that the effect of LMS on mathematics achievement differs significantly for the variables of year, education level, country and subject between subgroups.

In this direction, further research can focus on comparative studies of real course designs with virtual course designs. Additionally, considering that the use of LMS has a very small effect on mathematics achievement, and some negativities may have been mediated in terms of teacher knowledge, how the management system is used, student adaptation, and technological access, it can be suggested that this situation should be investigated with a qualitative methodology that provides more in-depth and detailed data. 
It has been discovered that the use of LMS is more effective in the subject of Arithmetic and Geometry and at the university level. For this reason, especially the teaching activities on this subject can be supported by LMS and contribute to the increase in the mathematics achievement of undergraduate and graduate students. When the studies included in the meta-analysis are examined with reference to the type of publication variable, it has been uncovered that there are very few studies in the form of articles examining mathematics achievement in the use of LMS. Article studies examining mathematics achievement in the use of LMS can be prioritized. When the effect of LMS use on mathematics achievement is analyzed by country subgroup, studies conducted in Turkey have been shown to have a greater impact. The reasons for this strong effect in the use of LMS can be further investigated. This meta-analysis research covers studies between 2005-2020 and in a specific database. In new meta-analysis research, the study can be replicated by updating this time interval and expanding the databases. The present meta-analysis study examined the effect of LMS use on mathematics achievement. In future investigations, different disciplines can be identified as moderators and the results of LMS on mathematics and other disciplines can be compared.

\section{Acknowledgements}

This study is a product of the master thesis of the first author under the supervision of second author.

\section{Öğrenme Yönetim Sistemi (ÖYS) Kullanımının Matematik Başarısına Etkisi: Meta- Analiz Çalıșması}

\section{Özet:}

$\mathrm{Bu}$ araştırmanın amacı, LMS (Learning Management System) kullanımının öğrencilerin matematik başarısına etkisini meta-analiz yöntemiyle incelemektir. Araştırmaya, 2005-2020 yılları arasındaki standart sapma, ortalama ve örneklem gibi verileri içeren 43 deneysel çalışma dahil edilmiştir. .Araştırmaya dahil edilen çalışmalardaki toplam örneklem sayısı 15.296'dır. Veriler Comprehensive Meta Analysis (CMA) yazılımı kullanılarak analiz edilmiştir.Rastgele etkiler modeline göre analiz yapıldıktan sonra, LMS kullanımının öğrencilerin matematik başarısı üzerindeki Cohen d etki değeri 0.363 olarak hesaplanmıştır. Bu etki büyüklüğü değerinin alt grup analizi sonuçlarına göre; LMS kullanımın matematik başarısı üzerindeki etkisinin örneklem, yayın türü, uygulama süresi ve uygulama yöntemi değişkenlerine göre alt gruplar arasında anlamlı olarak farklılaşmadığı görülmüştür. Diğer yandan, yıl, ülke, konu ve öğrenim düzeyi değişkenlerine göre alt gruplar arasında anlamlı bir farklılaşma olduğu bulunmuştur. 


\section{References}

Adzharuddin, N. A. \& Ling, L. H. (2013). Learning management system (LMS) among university students: Does it work? International Journal of E-Education, 3(3), https://doi.org/10.7763/IJEEEE.2013.V3.233.

Aguinis, H., Gottfredson, R. K., \& Wright, T. A. (2011). Best-practice recommendations for estimating interaction effects using meta-analysis. Journal of Organizational Behavior, 32(8), 1033-1043.

Anthony, C. (2015). Student Achievement in Mathematics: A Comparison Of Online And Direct Instruction. Doctor of Education. Northern Arizona University. Arizona.

Applebee, J. (2019). Student Usage of Open Educational Resource Learning Materials in Algebra 2. Doctor of Education. The State University. New Jersey.

Avgeriou, P., Papasalouros, A., Retalis, S., ve Skordalakis, M. (2003). Towards a pattern language for learning management systems, Journal of Educational Technology \& Society, 11-24, https://www.researchgate.net/publication/26393703.

Beam, P. \& Cameron, B. (1998). But what did we learn? Evaluating online learning as process. Paper Presented at the Sixteen Annual International Conference on Computer Documentation, 20(5), 258-264, https://doi.org/10.1145/296336.29639.

Belanger, M. (2018). Effects of Blended Learning and Gender on Mathematics Assessment in Elementary Fourth and Fifth Grade Students. Doctor of Education. Grand Canyon University. Arizona.

Borenstein, M., Hedges, L. V., Higgins, J. P. T. \& Rothstein, H. R. (2009). Introduction to meta-analysis. West Sussex: Wiley.

Boyd, A. C. (2018). Perceived Parent Involvement and a Technology-Enabled Workbook Intervention Effect Analysis on Summer Learning Loss for 6th and 7th Grade Students Attending a Pennsylvania K-12 Virtual School. Doctor of Education. The George Washington University. Washington.

Bradley, K. (2016). Evaluating The Effects of Mastery Learning in Postsecondary Developmental Mathematics. Doctor of Education. University of Louisiana. Louisiana.

Card, N. A. (2012). Applied meta-analysis for social science research. New York: The Guilford Press.

Chadwick, D. K. H. (1997). Computer-Assisted Instruction in Secondary Mathematics Classrooms: A Meta-Analysis. Master's Thesis. Drake University. United States-Iowa. 
Chan, K. K. \& Leung, S. W. (2014). Dynamic geometry software improves mathematical achievement: Systematic review and meta-analysis, Journal of Educational Computing Research, 51(3), 311-325, https//doi.org/10.2190/EC.51.3.c.

Chaney, T. A. (2016). The Effect of Blended Learning on Math and Reading Achievement in a Charter School Context. Doctor of Education. Liberty University. Liberty.

Chang, C., Jhu, K., Liang, C., Tseng, J.ve Hsu, Y. (2014). Is blended 3-learning as measured by an achievement test and self-assessment better than traditional classroom learning for vocational high school students? International Review of Research in Open and Distance Learning,15(2), 213-231, https://www.researchgate.net/publication/271831578.

Cheung, A. C. K. \& Slavin, R. E. (2013). The effectiveness of educational technology applications for enhancing mathematics achievement in K-12 classrooms: A metaanalysis, Educational Research Review, 9, 88-113, https://doi.org/10.1016/j.edurev.2013.01.001.

Cohen, J. (1960). A coefficient of agreement for nominal scales. Educational And Psychological Measurement, 20, 37-46.

Cohen, L., Manion, L., \& Morrison, K. (2007). Research methods in education (6th Edition). New York: Routledge.

Cole, J. \& Foster, H. (2008). Using moodle: Teaching with the popular open source course management system. Sebastopol, CA: O'Reilly Media.

Comfort, J. (2016). An Exploratory Study of the Relationship Between a Blended Learning Approach to Instruction and 5st Grade Student Performance in a Kansas Public School District. Doctor of Education. Studies and the Graduate Faculty of the University. Kansas.

Crowley, K. (2018). The Impact of Adaptive Learning on Mathematics Achievement. Doctor of Education. New Jersey City University. New Jersey.

Day, P. A. (2017). Effectiveness of the Career and College Promise Program in Increasing College Readiness at a Rural North Carolina Community College. Doctor of Education. The Gardner-Webb University School of Education. Gardner.

Deniz, S. (2019). Teknoloji Destekli Öğretimin Matematik ve Geometri Alanlarında Başarı ve Tutuma Etkisi Üzerine Bir Meta-Analiz Çalışması.(Yayınlanmamış Yüksek Lisans Tezi). Yüzüncü Y11 Üniversitesi. Van.

Dinçer, S. (2014). Eğitim bilimlerinde uygulamalı meta-analiz. Ankara: Pegem Akademi. 
Duval, S. \& Tweedie, R. (2000). Trim and fill: a simple funnel-plot-based method of testing and adjusting for publication bias in meta-analysis. Biometrics, 56(2), 455-463.

Ellis, R. K. (2009). Learning Managament Systems. Alexandria, VI: American Society for Training \& Development (ASTD).

Francis, J. (2016). Next Generation Online Math I Course Evaluation. Master of Arts in Educational Psychology. West Virginia University. West Virginia.

Gangaram, J. (2014). Blended and Online Student Performance and Persistence: A Comparative Study. Doctor of Education. North central University Graduate Faculty of the School of Education. Arizona.

Guzer, B. ve Caner, H. (2014). The past, present and future of blended learning: An in depth analysis of literature. Eastern mediterranean university, Faculty of Education, Department of Educational Sciences, Famagusta, North Cyprus, Social and Behavioral Sciences, 116(14), 4596 - 4603, https//doi.org/10.1016/j.sbspro.2014.01.992.

Higgins, J., Thompson, S. G., Deeks, J. J. ve Altman, D. G. (2003). Measuring inconsistency in meta-analysis, $B M J, 327,557-560$, https://www.researchgate.net/publication/10580837.

Huang, K. (2012). College Student Competency and Attitudes in Algebra Classes: A Comparison of Traditional and Online Delivery Methods in Exponents and Polynomials Concepts. Doctor of Education. Idaho State University Instructional Design in the College of Education. Idaho.

Ichinose, C. L. (2011). Learning Mathematics in The 21St Century: High School Students , Interactions While Learning Mathematics Online. Doctor of Philosophy. The Claremont Graduate University. California.

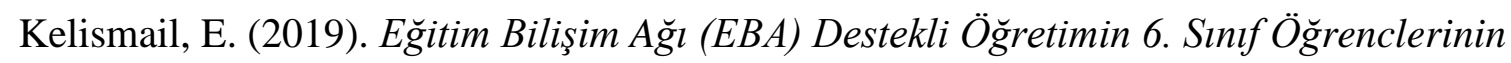
Cebirsel Ífadeler Alt Öğrenme Alanında Matematik Başarılarına ve Tutumlarına Etkisi. Yüksek Lisans Tezi. Gazi Üniversitesi Eğitim Bilimleri Enstitüsü. Ankara.

Korucu, A.T. \& Kabak, K. (2020). Türkiye hibrit öğrenme uygulamaları ve etkileri: Bir metaanaliz çalışması, Bilgi ve İletişim Teknolojileri Dergisi, 2(2), 88-112, https://dergipark.org.tr/tr/pub/bited/issue/58421/80322.

Kunzler, J. S. (2012). Exploring Customization in Higher Education: An Experiment in Leveraging Computer Spreadsheet Technology to Deliver Highly Individualızed Online Instruction to Undergraduate Business Students. Doctor of Education. Idaho State University. Idaho. 
Kwan lo, C. \& Foon, H. K. (2017). Using "First Principles of Instruction" to design secondary school mathematics flipped classroom: The findings of two exploratory studies, Educational Technology and Society, 20(1), 222-236, https://www.researchgate.net/publication/312045900.

Lee, W. C. (1990). The Effectiveness of Computer-Assisted Instruction and Computer Programing in Elementary and Secondary Mathematics: A Meta-Analysis. Doctor of Education. University of Massachusetts.

Lee, J. E. (2019). Examining the Effects of Discussion Strategies and Learner Interactions on Performance in Online Introductory Mathematics Courses: An Application of Learning Analytics. Doctor of Philosophy. Utah State University. Utah.

Li, Q. \& Ma, X. (2010). A meta- analysis of the effects of computer technology on school students mathematics learning, Educational Psychology Review, 22(3), 215-243, https//doi.org/10.1007/s10648-010-9125-8.

Liu, F. (2010). Factors Influencing Success in Online High School Algebra. Doctor of Philosophy. University of Florida. Florida.

Massoud, A., Iqbal, U. ve Stockley, D. (2011). Using blended learning to foster education in a contemporary classroom, Transformative Dialogues: Teaching \& LearningJournal, 5(2),111, https://www.researchgate.net/publication/254560902

McCray, M. (2019). FRACTIONVILLE: Impact of Gamification on Learning Foundational Fractions in the Third Grade, Doctor of Education. Kean University. New Jersey. Meylani, R. (2016). Short, Medium and Long Term Effects of an Online Learning Activity Based (OLAB) Curriculum on Middle School Students Achievement in Mathematics: A Quasi- Experimental Quantitative Study. Doctor of Philosophy. Arizona State University. Arizona.

Mills, J. J. (2016). A Mixed Methods Approach to Investigating Cognitive Load and Cognitive Presence in an Online and Face-To-Face College Algebra Course. Doctor of Education. Education at the University of Kentucky. Lexington. Kentucky.

Newberry, G. W. (2011). E-Learning Styles: A Study of Algebra Achievement for the Middle School E-Learner. Doctor of Philosophy. Capella University. Capella.

Norvell, E. A. (2017). Improving Mathematical Understanding: The Effects of Delivery Modes in Pre-Engineering Math Classes. Doctor of Philosophy. North central University School of School of Education. California. 
Nies, K. (2018). The Impact of the Use of Open Education Resources on College Student Success, Course Evaluation and Course Preference. Doctor of Philosophy. TUI University. California.

Nwaogu, N. E. (2012). The Effect of Aleks on Student's Mathematics Achievement in an Online Learning Environment and the Cognitive Complexity of the Initial and Final Assessments. Georgia State University. Doctor of Philosophy. Georgia.

Odom, S. B. (2006). The Effects of Self-Regulated Learning Strategies and Technology Instructional Strategies On the Math Achievement of Junior High Students. Doctor of Philosophy. University of South Alabama. Alabama.

Olpak, Y. Z., Baltaci, S., \& Arican, M. (2018). Investigating the effects of peer instruction on preservice mathematics teachers' achievements in statistics and probability. Education and Information Technologies, 23(6), 2323-2340.

Orwin, R. G. (1983). Afail safe N for effect size in meta-analysis, Journal of Educational Statistics, 8(2), 157-159, https://www.jstor.org/stable/1164923.

Osborne, S. F. (2020). Using Online Interventions to Address Summer Learning Loss in Rising Sixth-Graders. Doctor of Education. University of Missouri-St. Louis. Columbia.

Özerbaş, M. A. (2012). WebQuest öğrenme ortamının öğrencilerin akademik başarı ve tutumlarına etkisi, Ahi Evran Üniversitesi Kırşehir Ĕgitim Fakültesi Dergisi (KEFAD), 13(2), 299-315, https://dergipark.org.tr/tr/pub/kefad/issue/59489/85499.

Pope, H. (2013). Student Success Rate in Online Learning Support Classes Compared to Traditional Classes. Doctor of Education. Walden University. Washington.

PRISMA (2020). http://prisma-statement.org/prismastatement/Checklist.aspx

Renee, R. (2017). Effectiveness of Blended Learning in a Rural Alternative Education School Setting. Doctor of Education. Liberty University a Dissertation Presented in Partial Fulfillment of the Requirements for the Degree. Liberty.

Schenker, J. D. (2007). The Effectiveness of Technology Use in Statistics Instruction in Higher Education: A Meta-Analysis Using Hierarchical Linear Modeling. Doctor of Education. Retrieved From ProQuest Digital Dissertations. (AAT 3286857).

Smith, R. N. (2017). Perceptions and Effects of Classroom Capture Software on Course Performance Among Selected Online Community College Mathematics Students. Doctor of Education. Sam Houston State University. Houston. 
Steenbergen-Hu, S. \& Cooper, H. (2013). A meta-analysis of the effectiveness of intelligent tutoring systems on $\mathrm{K}-12$ students mathematical learning, Journal of Educational Psychology, 105(4), 970-987, https//doi.org/10.1037/a0032447.

Şimşek, Ö. (2010). Web Destekli Matematik Öğretiminde Kullanılan Video Derslerin Öğrenenlerin Türev Başarllarına Etkisi ve Öğrenenlerin Video Derslere İlişkin Görüşleri. Yüksek Lisans Tezi. Ege Üniversitesi Fen Bilimleri Enstitüsü. İzmir. Şahinoğlu, E. (2012). Moodle Ders Yönetimi Bilgi Sistemi Destekli Matematik Öğretiminin, Öğrencilerin Matematik Başarısına ve Matematik Dersine Yönelik Tutumlarına Etkisi. Yüksek Lisans Tezi. Gazi Üniversitesi Eğitim Bilimleri Enstitüsü Eğitim Bilimleri Anabilim Dalı Eğitim Teknolojisi Bilim Dalı. Ankara.

Tarazi, N. (2016). The Influence of the Inverted Classroom on Student Achievement and Motivation for Learning in Secondary Mathematics in the United Arab Emirates: A Quasi-Experimental Study. Doctor of Education. North central University. Arizona.

Tekin, O. (2018). Ters Yüz Sınıf Modelinin Lise Matematik Dersinde Uygulanması: Bir Karma Yöntem Çalışması. Doktora Tezi. Gaziosmanpaşa Üniversitesi Eğitim Bilimleri Enstitüsü. Tokat.

Telford, W. D. (2011). Investigating the Use of Destination Math in an Urban School District. Doctor of Philosophy. Texas A ve M University. Texas.

Thalheimer, W. \& Cook, S. (2002). How to calculate effect sizes from published research: A simplified methodology, Work-Learning Research, 1, 1-9, https://www.researchgate.net/publication/253642160.

Tokpah, C. L. (2008). The Effects of Computer Algebra Systems on Students Achievement in Mathematics. Doctor of Education. Kent State University, United States - Ohio.

Toth, P. F. (2013). Measuring efficiency of teaching mathematics online: Experiences with WeBWorK, Social and Behavioral Sciences, 89, 276 - 282, https://doi.org/10.1016/j.sbspro.2013.08.846.

Williamson, K. (2017). A Comparative Study on Web-Based Technology Support and Its Value on Student Success in Middle School Mathematics. Doctor of Education. North central University. Prescott Valley. Arizona.

Winn, D. (2016). The Effects of Blended Learning on Colorado Measures of Academic Success. Doctor of Education. Northern Arizona University. Arizona. 
Woolley, S. ve Ludwig, S. (2000). Online learning communities: Vehicles for collaboration and learning in online Learning environments. Canada: Association for the Advancement of Computing in Education (AACE).

You, J. W. (2015). Identifying significant indicators using LMS data to predict course achievement in online learning, Internet and Higher Education, 29, 23-30, https://doi.org/10.1016/j.iheduc.2015.11.003.

Young, J. \& Hamilton, C. (2018). Technology effectiveness in the mathematics classroom: A systematic review of meta-analytic research, Journal of Computers Education, 5(2), 133-148, https://www.researchgate.net/publication/325105360.

Zenati, L. (2020). Implementing Asynchronous Discussion as an Instructional Strategy in the Developmental Mathematics Courses to Support Student Learning. Doctor of Education. Illinois Institute of Technology. Chicago. 